\title{
Hydrologic properties and sediment transport in ephemeral streams
}

\author{
L. G. Castillo \& M. D. Marin \\ Civil Engineering Department, Technical University of Cartagena, Spain
}

\begin{abstract}
It is known that in semiarid regions with steep morphology and irregular rainfall regime areas floods present with a high proportion of solid material transport. Furthermore, climate change will increase flash flood phenomena, and will make it necessary to control them to minimize their destructive effects.

In order to design effective control and intake systems in semiarid regions, it is necessary to know the hydrologic and hydraulics characteristics of ephemeral rivers.

According to the results in Las Angustias Gully (Isla de la Palma-Spain), and based on their similarity to the semiarid watersheds of the Region of Murcia (Spain), the first results of Mergajón, Intermedia Gully and Hoya de España Gullies (Murcia) were studied in order to establish a general criteria of calculation in these regions.

Based on the results obtained with distributed and aggregated hydrologic models, in this paper the authors try to analyse the principal hydrologic properties and sediment transport in ephemeral streams.

Keywords: semi-arid region, sediment transport, resistance coefficient, ephemeral river, hyperconcentrated flow.
\end{abstract}

\section{Introduction}

Semi-arid regions are characterized by an irregular rainfall which confers on them, among other characteristics, reduced, or almost absent, vegetation coverage. In addition, a direct effect on the frequency and intensity of precipitation is being caused by climate change, so the precipitation is less frequent and more intensive. The combination of these two elements, heavy rains and potentially erodible areas, explains the fact that hyperconcentrated flows are 
becoming more usual. The torrential rainfall, which is scarce but very intense, means that these gullies, which are generally inactive, can carry large amounts of water and sediment in these events.

There are three reasons that justify the study of specific intake systems for semi-arid regions: (1) it is not possible to use conventional intake systems (damreservoir) because the high concentration of sediment makes them useless in a short time period, (2) to take water, a very scarce and necessary resource, and (3) this type of structure makes possible to minimize destructive effects of flash floods.

To analyze the design parameters of specific intake systems, it is necessary to characterize the ephemeral rivers where these structures will be placed. The knowledge of the hydrological and hydraulic characteristics, typical of these areas, the quantification of sediment transport capacity is essential.

Research on sediment transport has been done for decades, without obtaining a really satisfactory equation which interrelates the flow and sediment properties properly. Consequently, we have examined other experiences in the sediment transport calculation for hyperconcentrated flows. We find in Spain some of them as Las Angustias Gully, located in the Isla de la Palma (Canary Islands).

According to the results presented at Las Angustias Gully, and looking at their similarity to the semi-arid watersheds of the Region of Murcia, one of the objectives of the Hidr@m group is to apply and analyze the methodology developed by Castillo et al. $[1,2]$, Castillo [3, 4], in order to establish a general criteria of calculation in these regions. Therefore, three gullies located in Albujón Gully (Campo de Cartagena), were studied and first results obtained in sediment transport estimation will be presented in this paper.

\section{Description of the Mediterranean basins in study}

The Albujón Gully, which is located in Región de Murcia (Spain), constitutes the principal natural drainage of the Campo de Cartagena region. The river basin has a total area of around $694 \mathrm{~km}^{2}$.

Albujón basin has moderate elevations although its slopes increase between $0.4 \%$ close to the mouth and $5.8 \%$ in the header areas. Its morphology is dominated by great plain of irrigated crops in the lower part of the basin, fruits and herbs in the middle-high and scattered areas of woodland in the mountains (coniferous, scrub and woodland). In reference to its lithology, the middle and lower areas are dominated by glacis and crust edges, and in the lower area red clay and wider range of soils such as carbonates and sandstones can be found. These formations give the soil a character less permeable and imperfect drainage.

The Albujón Gully is formed by 17 sub-basins with areas of around $50 \mathrm{~km}^{2}$. Three of them, Mergajón Gully, Intermedia Gully and Hoya de España Gully (fig. 1), have been selected for the application of the methodology developed in the Las Angustias Gully. Mergajón has been chosen because of its similar geomorphological characteristics (area and slope), and hydrological and 


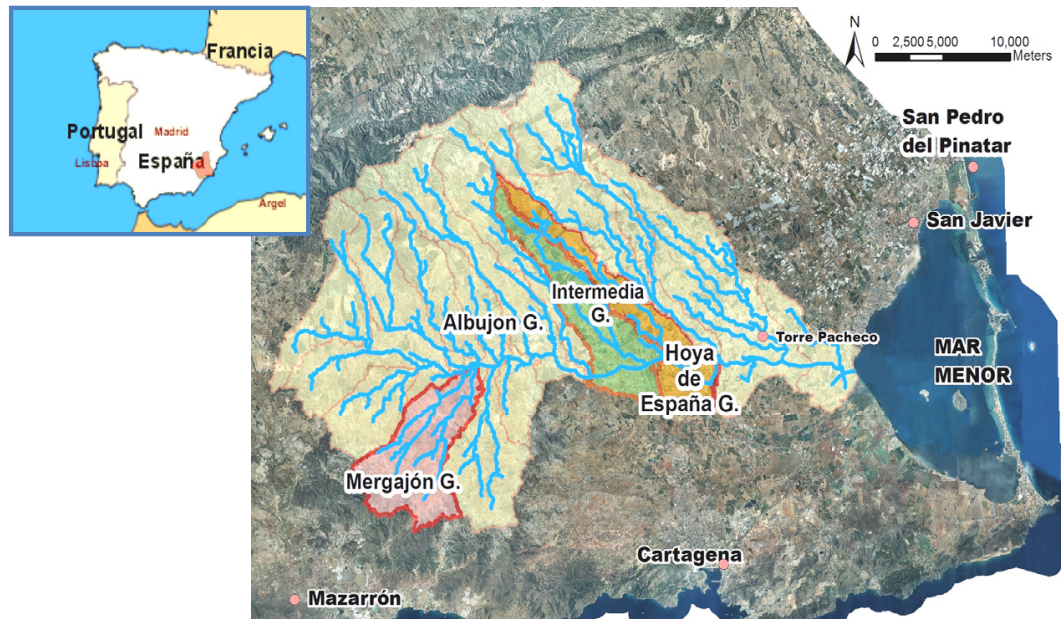

Figure 1: Situation of Mergajón, Albujón intermedia and Hoya de España basins.

hydraulic characteristics with Las Angustias. The Intermedia and Hoya de España basins have different characteristics in slopes and in the grain-size distribution curves.

\section{Hydrological characterization of the basins}

The characterization of the main hydrographic features in a basin is a very important issue in their hydrological studies. Attending to the characteristics of semi-arid and arid zones, the simulation hydrological model has to be chosen carefully. Salas [5] points out that distributed models either continuous or event, are more flexible and more useful in semi-arid basins. For this reason, among others, at first approximation, HEC HEC-HMS developed by U.S. Army Corps of Engineers of the United States of America (USACE), has been used for the calculation of flows.

The Curve Number $(\mathrm{CN})$ of Soil Conservation Service (SCS) has been used for estimating abstraction from storm rainfall. It was selected because it is the most extended and probed method, and it is widely accepted for use in Spain. Considering there is limited information on actual events in the basins, the SCS unit hydrograph has been chosen to model rainfall-runoff transformation. For modeling channel flow we applied two different routing models depending on the river slope. Thus, for rivers with medium-high slopes $(>1 \%)$ the MuskingumCunge routing model has been selected (Las Angustias and Mergajón basins). However, for basins with medium-low slopes (Albujón Intermedia and Hoya de España basins), the kinematic wave method is more adequate to use.

The delimitation of the Albujón basin and aggregation of its sub-basins have been carried out using the Geospatial Hydrologic Modelling Extension (HECGeoHMS), ArcView GIS and its Spatial Analyst extension from the 
Environmental Systems Research Institute, Inc. (ESRI). Digital Terrain Model (DTM) of 4x4 m -developed in 2009 as part of project "Natmur-08", commissioned by la Consejería de Desarrollo Sostenible y Ordenación del Territorio of Región de Murcia - has been used (fig. 2a).

Watersheds' Curves Numbers (CN) have been calculated using the Spanish version of the SCS method. In this version, $\mathrm{CN}$ is estimated using the parameter $P_{0}$ "runoff threshold", which was defined by Témez [6] as $P_{0}=0.2 S$, where $S$ is the potential maximum retention. The relationship between $\mathrm{CN}$ and $P_{0}$ is $\mathrm{NC}=5080 /\left(50.8+P_{0}\right)$. The $P_{0}$ value was estimated as function of terrain slope, soil type, land use, and antecedent moisture. According to these parameters a map of $\mathrm{CN}$ was obtained (fig. 2b).

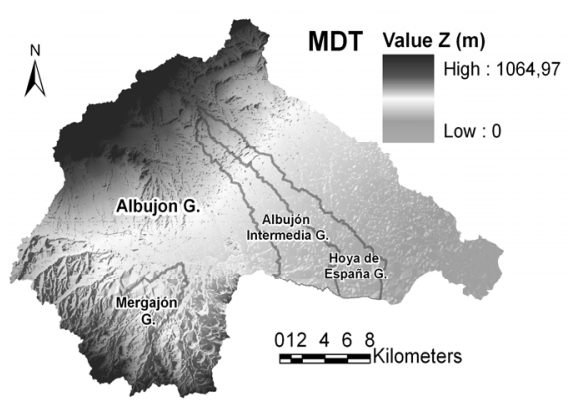

(a)

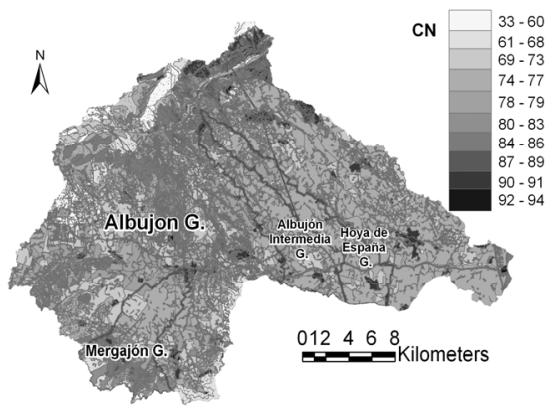

(b)

Figure 2: (a) DTM of basin and its sub-basin, (b) Curve number CN.

Sometimes in semiarid areas, it is not possible to make a prediction and estimation of rainfall due to few instrumentation and scarce hydro meteorological information (few rain gages with very short historical series). This particularity makes very difficult the use of methodologies based on satellite imagery and radar. In this case it is necessary to apply various methodologies that use historical data to rain gauge and daily records of rainfall and storm patterns of design, to simulate the spatial-temporal variability of rainfall.

To obtain at each basin the maximum daily rainfall in different return periods, it was made a study that includes: (1) statistical analysis of maximum daily rainfall (2) the precipitation pattern, its value and the spatial and time distributions (design storms).

For statistical analysis of rainfall were studied registers from 1933 to 2009 (17 rain gages) which are located close and inside Albujón watershed. In the data study has been taken into account the temporal and spatial distribution. Data from different rain gages were compared and analysed using the double mass method. After the rectification of some inconsistencies, the data obtained has been modified by a correction factor (a) which depends on the numbers of data observed (World Meteorological Organization, WMO). 
Then frequency distributions of this data were done with different theoretical distribution as TCEV, GEV, LP3, Gumbel and SQRT-Etmax. The rainfalls of each gage for each return period were obtained and it was taken the values which were more unfavourable. The required watersheds precipitations depths were calculated from gages, using Thiessen polygon method. Finally, other two factors correction was applied: (b) factor proposed by Témez [6] to take into account the spatial variability of the rainfall over the watershed area, and (c) curves proposed by WMO for calculating areal depth as a percentage of point precipitation values. The definitive values of correction factors and daily maximum precipitation for each watershed and return period are presented in table 1 .

Table 1: $\quad$ Basins hydraulic characteristics.

\begin{tabular}{|c|c|c|c|c|c|c|c|c|c|c|}
\hline \multicolumn{4}{|c|}{$\begin{array}{c}\text { Correction factors for all basins: } \\
(\mathrm{a})=1.13 ;(\mathrm{b})=0.89 ;(\mathrm{c})=0.99\end{array}$} & \multicolumn{1}{c|}{ Daily maximum rainfall $(\mathrm{mm})$} \\
\hline Basin & $\begin{array}{c}\text { Area } \\
\left(\mathrm{Km}^{2}\right)\end{array}$ & $\begin{array}{c}L \\
(\mathrm{~km})\end{array}$ & $\begin{array}{c}i \\
(\mathrm{~m} / \mathrm{m})\end{array}$ & $\begin{array}{c}\text { Time } \\
(\mathrm{h})\end{array}$ & $P_{1.4}$ & $P_{5}$ & $P_{10}$ & $P_{50}$ & $P_{500}$ & $P_{1000}$ \\
\hline Intermedia & 48 & 25.230 & 0.0082 & 24 & 30 & 78 & 99 & 145 & 210 & 229 \\
\hline H. Españá & 48 & 27.241 & 0.0082 & 24 & 32 & 74 & 92 & 131 & 187 & 204 \\
\hline Mergajón & 52 & 12.874 & 0.0274 & 24 & 36 & 92 & 118 & 176 & 257 & 281 \\
\hline Angustias & 49 & 12.982 & 0.0392 & 24 & 101 & 166 & 195 & 257 & 344 & 370 \\
\hline
\end{tabular}

To take into consideration the distribution of rainfall it has been considered a rainfall pattern according to the way in which these events occur in the study area. Based on a storm duration of $24 \mathrm{~h}$ and a time interval of 15 minutes, using alternating block method it was designed a hyetograph where $80 \%$ of rainfall were concentrated during hours 8 to 16 , and the rest $(20 \%)$ were distributed into 2 symmetric parts of 8 hours each one (from hours 0 to 8 , and from 16 to 24).

The SCS rainfall-runoff transformation model requires the calculation of lag time, $T_{\text {lag }}$, normally as function of concentration time, $T_{c}$. In Spain is usual to use the following expression: $T_{\text {lag }}=0.35 T_{c}$, where $T_{c}=0.3\left(L / i^{0.25}\right)^{0.76} . L$ is main course length $[\mathrm{km}]$ and $i$ is the slope $[\mathrm{m} / \mathrm{m}]$ (Témez [6]). Results are given in table 2 .

Table 2: $\quad T_{c}$ and $T_{\text {lag }}$ values and peak outflow discharge for each basin.

\begin{tabular}{|c|c|c|c|c|c|c|c|c|}
\cline { 3 - 10 } \multicolumn{2}{c|}{} & \multicolumn{5}{c|}{ Peak outflow discharge $\left(\mathrm{m}^{3} / \mathrm{s}\right)$} \\
\hline Blbujón Intermedia & $T_{c}(\min )$ & $T_{\text {lag }}(\min )$ & $Q_{1,4}$ & $Q_{5}$ & $Q_{10}$ & $Q_{50}$ & $Q_{500}$ & $Q_{1000}$ \\
\hline Hoya de España & 532 & 179 & 5 & 68 & 106 & 198 & 336 & 379 \\
\hline Mergajón & 290 & 186 & 6 & 55 & 84 & 157 & 270 & 305 \\
\hline Las Angustias & 180 & 63 & 121 & 148 & 229 & 422 & 701 & 786 \\
\hline
\end{tabular}

Similarly, for the Muskingum-Cunge and Kinematic wave channel routing models, several cross sections and roughness coefficients should be obtained from the MDT. Finally, it was obtained the stream flow hydrographs for each return period. In table 3 we can see values of $T_{c}$ and $T_{\text {lag }}$ and the peak discharge for the different Albujón sub-basins and of Las Angustias. Comparing results of 
Mergajón with Las Angustias, it is noticed that they are very similar either in precipitation as in liquid flow (for return periods larger than 50 years). If we analyse flows for the different basin in relation with area and rainfall then the liquid flows in Albujón Intermedia and Hoya de España, are much lower than the Mergajón (similar areas and reduced rainfall approximately in 18\%). This fact is caused by their different watersheds shapes, which is reflected in the values of $T_{c}$ and $T_{\text {lag. }}$.

Although the use of event models semi-distributed is recommended for the case of basins with little or no data of events, it is interesting to study these ephemeral rivers with distributed models and to compare the results. MIKE SHE (DHI [7]) software developed and extended by DHI Water \& Environment has been used for this purpose. MIKE SHE is a physically based, distributed, integrated hydrological and water quality modelling system. It covers the major processes in the hydrologic cycle and includes process models for evapotranspiration, overland flow, unsaturated flow, groundwater flow, and channel flow and their interactions.

At first approximation we built a MIKE SHE model of Mergajon Gully, in which only the overland flow process was included because we just required an event simulation. To implement the Mike SHE model we used input values equivalent to those used in our HMS model. They included precipitation, topography, and detention storage value $D S$, which was assimilated to $P_{0}$ value. We ran the simulation in three different rainfall scenarios (fig. 3, table 3).
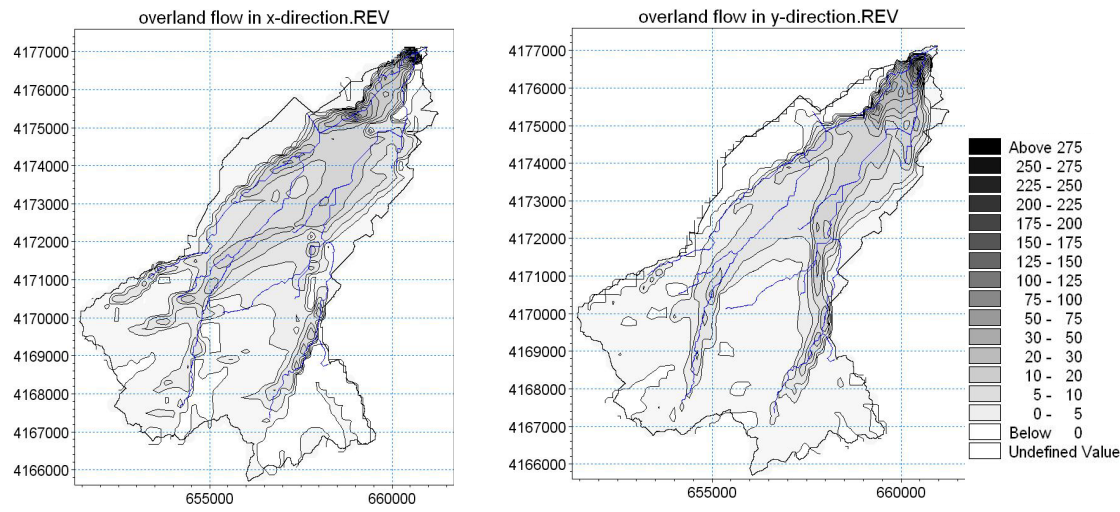

Figure 3: $\quad$ Maximum overland flow in $\mathrm{x}$ and $\mathrm{y}$ directions for T500 years.

Table 3: $\quad$ Peak outflow discharge values and time to reach them.

\begin{tabular}{|c|c|c|c|}
\cline { 2 - 4 } \multicolumn{1}{c|}{} & Pd T1.4 & Pd T50 & Pd T500 \\
\hline$D S=P_{0}(\mathrm{~mm})$ & 14 & 14 & 14 \\
\hline $\mathrm{CN}$ & 78 & 78 & 78 \\
\hline HEC HMS $Q_{\max }\left(\mathrm{m}^{3} / \mathrm{s}\right)$ & 14 & 422 & 701 \\
\hline Time to peak flow (h) & $14: 15$ & $13: 45$ & $13: 45$ \\
\hline Mike SHE $Q_{\max }\left(\mathrm{m}^{3} / \mathrm{s}\right)$ & 24.2 & 420.8 & 558.9 \\
\hline Time to peak flow (h) & $19: 09$ & $13: 36$ & $13: 10$ \\
\hline
\end{tabular}


Comparing the maximum outflow values and time to reach them obtained in the HEC-HMS model and MIKE SHE model (table 3), we can see that the results obtained by MIKE SHE are higher than HMS for low return period ( T1.4 years). Nevertheless the same values are similar in both models for T 50 years, and MIKE SHE model results are lower than HMS model for T500 years.

Times to peak flows are very similar in the two models, except in the case of T1.4 years where the MIKE SHE model is until five hours greater than the HMS model.

\section{Hydraulic characterization: study of sediment transport}

With regards to the source of sediments, the transport may be divided in: (1) wash load which include very fine material and is transported in suspension, and (2) total bed transport which is transported on bed and in suspension (depending on the sediment size and flow velocity). The main properties of sediment and its transport are: the particle size, shape, density, sedimentation velocity, porosity and concentration. Two types of information are required: the characteristic diameters of the bed material and hydraulic information (flow characteristics). Table 4 shows grain-size distribution curves of the four gullies analysed and table 5 shows the principal hydraulic characteristics.

Table 4: Grain-size distribution of the gullies.

\begin{tabular}{|c|c|c|c|}
\hline Basin / Diameter & $D_{16}(\mathrm{~mm})$ & $D_{50}(\mathrm{~mm})$ & $D_{84}(\mathrm{~mm})$ \\
\hline Las Angustias & 1.3 & 28 & 870 \\
\hline Intermedia & 1.3 & 4.9 & 22.5 \\
\hline Hoya de España & 2.5 & 10.5 & 19.7 \\
\hline Mergajón & 0.6 & 3.5 & 14.7 \\
\hline
\end{tabular}

Table 5: $\quad$ Principal hydraulic characteristic of the basin.

\begin{tabular}{|c|c|c|c|c|c|c|c|}
\hline Basin & $Q_{T}\left(\mathrm{~m}^{3} / \mathrm{s}\right)$ & $y / D_{84}$ & $Q_{100}\left(\mathrm{~m}^{3} / \mathrm{s}\right)$ & $R_{h} / D_{50}$ & $Q_{T}\left(\mathrm{~m}^{3} / \mathrm{s}\right)$ & $\begin{array}{c}\text { Weight } \\
\text { conc. } \\
(\%)\end{array}$ & $\sigma_{g}$ \\
\hline Intermedia & $\mathrm{Q}_{10}=106$ & 40 & 379 & 170 & $\mathrm{Q}_{10}=105.8$ & 0.30 & 4.15 \\
\hline H. España & $\mathrm{Q}_{10}=84$ & 4 & 305 & 87 & $\mathrm{Q}_{10}=105.8$ & 0.32 & 2.79 \\
\hline Mergajón & $\mathrm{Q}_{1.4=} 14$ & 23 & 786 & 442 & $\mathrm{Q}_{50}=105.8$ & 0.28 & 5.03 \\
\hline
\end{tabular}

\subsection{Estimation of manning resistance coefficient}

The calculation of the flow characteristics depends mainly on the resistance coefficient, hydraulic radius and longitudinal slope. Following the methodology applied in Castillo et al. [2], four aspects are checked to determine hydraulic characteristics of the flow: (1) macro roughness, (2) bed form resistance, (3) hyper concentrated flow, and (4) bed armouring phenomenon.

In all the studied cases we are facing a macro roughness problem with low return periods flows because of $y / D_{84}<50$, where $y$ is depth [m]. On the other 
hand, neither bed form resistance nor a possible rise of resistance for the variation in flow density and viscosity are explicitly taken into account because of $R_{h} / D_{50}<2.000$ - where $R_{h}$ is hydraulic radius- and for the sediments concentration in weight is inferior to $10 \%$ in all of cases. Nevertheless, bed armouring phenomenon happens in Mergajón and Albujón Intermedia Gullies because size distribution typical deviation is extended or graduated $\left(\sigma_{\mathrm{g}}>3\right)$, but it is not presented in Hoya de España Gully (table 5).

For the estimation of the roughness coefficient in the case of macro rough flows, different formulae analysed, Castillo et al. [1, 2] have been applied. The formulae are calculated coupling iteratively the hydraulic characteristics with the sediment transport and so, to obtain grain mean roughness. Table 6 shows those formulations which best fitted to the mean value.

Table 6: $\quad$ Resistance coefficient for macro-rough flows.

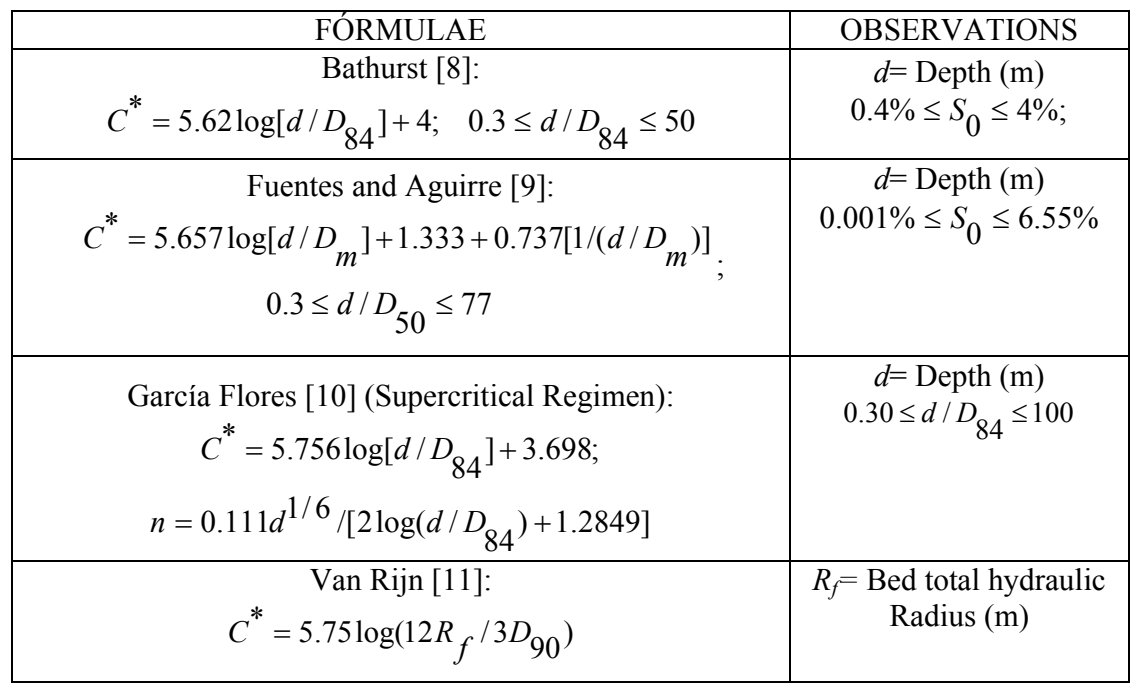

The Manning coefficients obtained from the different analysed methods show some spread, but in general, these values tend to diminish when the flow increases. These values of grain roughness are more significant in Las Angustias Gully, compared to the total value of Manning. They have been increased by 0.01 units to considerer the shape of the section and the existing vegetation. The coefficients for the calculation of sediment transport are: Las Angustias (0.104 $0.062)$, Mergajón (0.033 - 0.032), Intermedia Albujón (0.035 - 0.033) and in the Hoya de España (0.037 - 0.034).

\subsection{Estimation of sediment transport}

Castillo et al. [2] analysed 12 formulations that have been applied to evaluate sediment transport capacity in each gully. Liquid flows of different return periods (between 1.4 and 1,000 years) have been calculated. Table 7 shows the 
Table 7: $\quad$ Sediment transport formulations that best performing.

\begin{tabular}{|c|c|}
\hline FÓRMULAE & OBSERVATIONS \\
\hline $\begin{array}{l}\text { Einstein and Barbarrosa [13]: } \\
i_{B} g_{B i}=\Phi_{*} i_{b} \gamma_{S}\left(g \Delta D_{i}^{3}\right)^{1 / 2} ; g_{B T}=g_{B}+g_{B S} \\
i_{S} g_{B s i}=i_{B} g_{B i}\left\{P_{E} I_{1}+I_{2}\right\} ; \\
i_{B T} g_{B T i}=i_{B} g_{B i} \cdot\left\{1+P_{E} I_{1}+I_{2}\right\} \\
g_{B T}=\sum_{i=1}^{n} i_{B T i} g_{B T i} ; \Psi_{*}=\xi Y\left(\beta / \beta_{x}\right)^{2} \Psi^{\prime} ; \\
\xi=f\left(D_{i} / X\right) ; Y=f\left(D_{65} / \delta^{\prime}\right) ; K_{S}=D_{65} ; \\
\beta_{x}=\log \left(10.6 X / \Delta^{\prime}\right) ; \Psi^{\prime}=\Delta^{\prime}\left[D_{i} /\left(R^{\prime} S\right)\right] ; \Delta^{\prime}=\frac{K_{S}}{\chi}\end{array}$ & $\begin{aligned} P_{E}= & 2.303 \log \left(\frac{30.2 d}{\Delta^{\prime}}\right) \\
I_{1}= & 0.216 \frac{E^{Z-1}}{(1-E)^{Z}} \int_{E}^{1}\left(\frac{1-y}{y}\right)^{Z} d y \\
I_{2}= & 0.216 \frac{E^{Z-1}}{(1-E)^{Z}} \int_{E}^{1}\left(\frac{1-y}{y}\right)^{Z} \ln (y) d y \\
E= & a / d ; a=2 D_{i} ; z=w /\left(K \beta U_{*}^{\prime}\right. \\
\chi= & f\left(K_{S} / \delta^{\prime}\right) ; U_{*}^{\prime}=\sqrt{g R^{\prime} S} \\
& d=\operatorname{depth}(\mathrm{m}) ; \mathrm{S}=\text { slope }\end{aligned}$ \\
\hline $\begin{array}{l}\text { Meyer- Peter and Müller [14]: } \\
\gamma\left(K_{s} / K_{r}\right)^{3 / 2} R_{S} I= \\
=0.047 \gamma_{s}^{\prime} D_{m}+0.25 \gamma_{S}^{\prime 2 / 3} \rho^{1 / 3}\left(g_{B T} / \gamma_{s}\right)^{2 / 3} \\
K_{r}=\frac{26}{D_{90}^{1 / 6}} ; K_{m}=\frac{1}{n} ; K_{w}=\frac{1}{n_{w}} \\
K_{S}=\frac{B^{2 / 3} K_{m} K_{w}}{\left\{K^{3 / 2}{ }_{w}(B+2 d)-K_{m}^{3 / 2} 2 d\right\}^{2 / 3}}\end{array}$ & $\begin{array}{c}g_{B T}=\text { Unit total bed transport in } \\
\text { weight }(\mathrm{T} / \mathrm{ms}) ; \\
b=\text { width }(\mathrm{m}) ; d=\text { depth }(\mathrm{m}) ; \\
n_{w}=\text { roughness coefficient of } \\
\text { banks }\end{array}$ \\
\hline $\begin{array}{c}\text { Bathurst et al. [15]: } \\
\phi=\left(2.5 S^{3 / 2} /\left[(\Delta+1) D_{50}\left(g \Delta D_{50}\right)^{1 / 2}\right]\right)\left[q-q_{c}\right] \\
\mathrm{D}_{50}: q_{c}^{*}=\frac{q_{c}}{g^{1 / 2} D_{50}^{3 / 2}}=0.15 S^{-1.12} \\
\mathrm{D}_{16}: q_{c}^{*}=\frac{q_{c}}{g^{1 / 2} D_{16}^{3 / 2}}=0.21 S^{-1.12}\end{array}$ & $\begin{array}{c}S=\text { slope } q=\text { unit liquid flow; } \\
q_{c}=\text { critical flow; } \\
\Delta=\text { dimensionless apparent } \\
\text { specific gravity. }\end{array}$ \\
\hline $\begin{array}{l}\text { Yang S. [16]: } \\
C=\frac{g_{t}}{V h}=k \frac{\gamma_{S}}{\gamma_{S}-\gamma} \frac{\tau_{o}}{V h} \frac{u_{*}^{\prime 2}-u_{*}{ }^{2}}{w} ; k=6-12.5 \\
u_{*}^{\prime}{ }^{2}=\text { grain-shear velocity; } u_{*_{c}}{ }^{2}=\text { Shields grain } \\
\text { critical-shear velocity, } \gamma_{=} \text {water specific weight. }\end{array}$ & $\begin{array}{c}C=\text { weight total sediment } \\
\text { concentration; } g_{t}=\text { total bed } \\
\text { transport per width; } h=\text { hydraulic } \\
\text { radius or water depth; } V=\text { mean } \\
\text { velocity; } d=\text { sediment size; } \\
\gamma_{\mathrm{s}}=\text { specific weight of sand; } \\
w=\text { particle fall velocity; } \tau_{o}=\text { shear } \\
\text { stress. }\end{array}$ \\
\hline
\end{tabular}

principal formulations and their results are around of the mean value. In fig. 4 can be appreciated that solid flow of Albujón sub-basins are lower than Las Angustias. Only Mergajón results are comparable with those obtained in Las Angustias, being that results lower than Las Angustias. The difference between them increases as the liquid flow increases. 


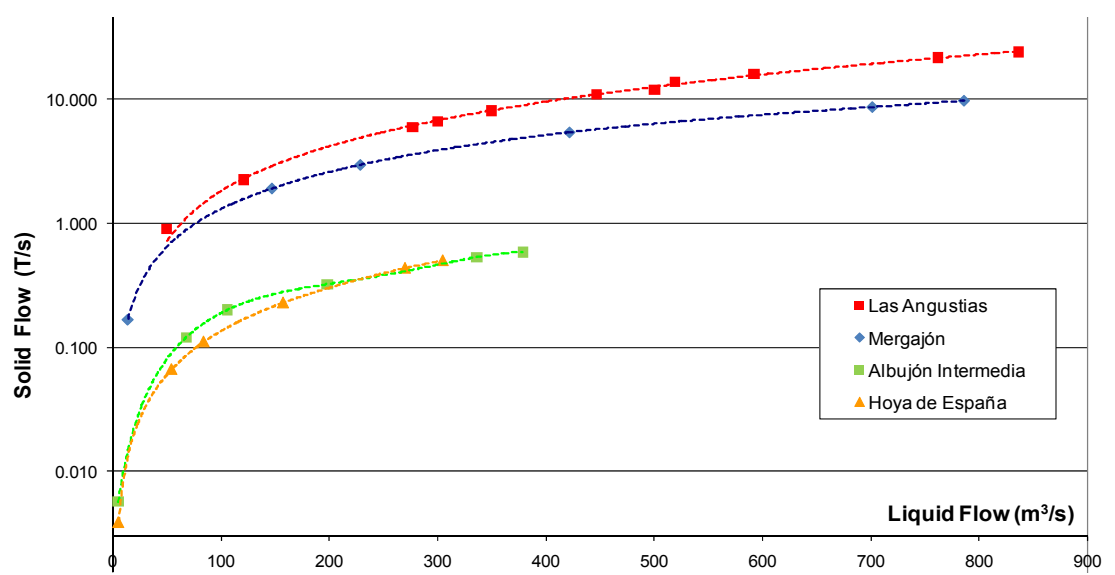

Figure 4: Comparison between total bed transport $(\mathrm{T} / \mathrm{s})$ as a function of liquid flow $\left(\mathrm{m}^{3} / \mathrm{s}\right)$.

To compare the proportions of bed transport and suspended bed transport, we applied Einstein-Barbarossa method. Table 8 and fig. 5 show that in Las Angustias, for the lowest flows, the bed transport is really higher than suspended bed transport ( $84 \%$ vs $6 \%$ for $Q_{1,4}=121 \mathrm{~m}^{3} / \mathrm{s}$ ), ratio which increases until $61 \%$ vs $39 \%$ for $Q_{1.000}=836 \mathrm{~m}^{3} / \mathrm{s}$. In Mergajón, with low return period flows $\left(Q_{1,4}=\right.$ $\left.14 \mathrm{~m}^{3} / \mathrm{s}\right)$ the ratio of bed transport is higher than suspended bed transport $(70 \%$ vs $30 \%)$. However for higher liquid flows $\left(\mathrm{Q}_{1000}=786 \mathrm{~m}^{3} / \mathrm{s}\right)$ the bed transport is much lower than suspended bed transport (12\% vs $18 \%$ ), an inverted trend to Las Angustias. Aguirre-Pe et al. [12] point that for slopes between 0.01 and 0.20 , bed transport can reach about $50 \%$ of total bed transport.

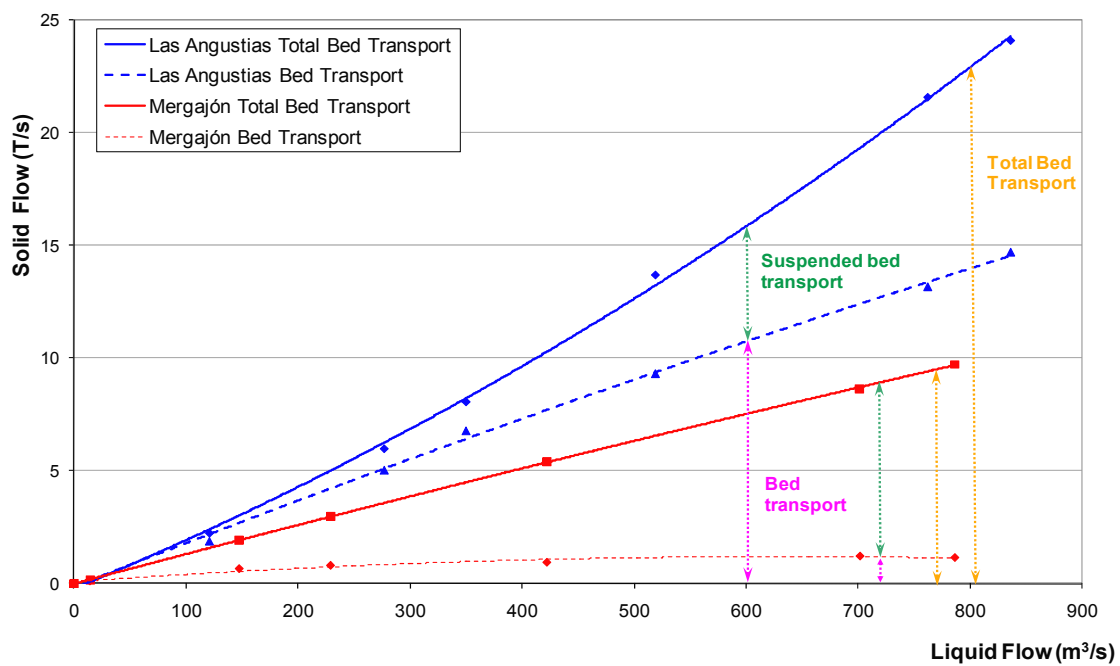

Figure 5: Comparison between Las Angustias and Mergajón basins. 
In contrast to this, in rivers with low slope bed transport can be around 5 to $20 \%$ of total bed transport. Mergajón Gully, although can be considered as a mountain river based on its slope (0.027), has a grain-size characteristic curve typical of an alluvial river. This fact explains the inverted trends regarding to Las Angustias. Albujón Intermedia and Hoya de España Gullies although can be considered properly as alluvial river, however according to the values shown in table 8, the rates of bed transport are higher than suspended transport in all flows. The reason of this performance could be that in these basins flows are lower than in Mergajón and these flows are not able to mobilize all suspended bed transport.

Table 8: $\quad$ Main results of bed and suspended bed transport rates.

\begin{tabular}{|c|c|c|c|c|c|c|}
\hline Basin & $\begin{array}{c}Q_{T 1.4} \\
\left(\mathrm{~m}^{3} / \mathrm{s}\right)\end{array}$ & $\begin{array}{c}\text { Bed } \\
\text { transport }\end{array}$ & $\begin{array}{c}\text { Suspended } \\
\text { bed transp. }\end{array}$ & $\begin{array}{c}Q_{T 1000} \\
\left(\mathrm{~m}^{3} / \mathrm{s}\right)\end{array}$ & $\begin{array}{c}\% \text { Bed } \\
\text { transport }\end{array}$ & $\begin{array}{c}\text { Suspended } \\
\text { bed transp. }\end{array}$ \\
\hline Angustias & 121 & $84 \%$ & $16 \%$ & 836 & $61 \%$ & $39 \%$ \\
\hline Mergajón & 14.3 & $70 \%$ & $30 \%$ & 786 & $12 \%$ & $88 \%$ \\
\hline Intermedia & 5.2 & $88 \%$ & $12 \%$ & 379 & $51 \%$ & $49 \%$ \\
\hline H. España & 5.6 & $97 \%$ & $3 \%$ & 305 & $66 \%$ & $33 \%$ \\
\hline
\end{tabular}

\section{Summary and conclusions}

Albujon basin has two types of sub-basins, mountain and alluvial watersheds. In this paper the hydrologic and hydraulic characterizations of three Albujon subbasins have been made: Mergajón Gully which can be classified as mountain river basin, and Albujon Intermedia and Hoya de España Gullies which can be categorized as alluvial river basin.

Regarding hydrological characterization of ephemeral rivers, it can be concluded that it's important to choose the correct formulae for calculating $T_{\text {lag }}$ and $T_{c}$, and to make an appropriate design storm that represents spatial and temporal variability of rainfall in the area. Also, we can say that for alluvial rivers, the use of the kinematic wave channel routing is more appropriate than the Muskingum-Cunge model.

Although the use of event models semi-distributed is recommended for the case of basins with little or no data of events, the study of these ephemeral rivers with distributed models results a very interesting option for improve the knowledge of the different physical process in these hydrological systems.

Finally and with regard to characterization and calculation of sediment transport capacity, the study shows that the methodology proposed is adequate for ephemeral rivers. In addition we want to emphasize on the importance of sampling in the calculation of sediment transport.

\section{Acknowledgements}

The research is part of the project PEPLAN: "Hydrological modelling in SemiArid Regions. Subproject 3: Modelling of intakes in ephemeral rivers". The authors are grateful for financial support of Consejería de Universidades, Empresa e Investigación of Comunidad Autónoma of Región de Murcia. 


\section{References}

[1] Castillo, L., Santos, F., Ojeda, J., Calderón, P. \& Medina, J.M., Importancia del muestro y limitaciones de las formulaciones existentes en el cálculo del transporte de sedimentos. Proc. of the XIX IAHR, Córdoba, Argentina, 2000.

[2] Castillo, L., Martín Vide, J.P. \& Marín, M.D., Coeficientes de resistencia, transporte de sedimentos y caudal dominante en regiones semiáridas. Proc. of the I Jornadas de Ingeniería del Agua, JIA, CEDEX. Madrid, 2009.

[3] Castillo, L., Estimation of sediment transport and dominant flow in hyperconcentrated flows. Proc. of the ICHE, Brisbane, Australia, 2004.

[4] Castillo, L., Discussion about prediction of bed material discharge. J. Hydraulic Research, 45 (2), pp. 425-428, 2007.

[5] Salas, J.D., Hidrología de zonas áridas y semiáridas. Ingeniería del Agua, 7(4), pp.409-429, 2000.

[6] Témez, J.R., Generalización y mejora del método racional, Versión de la Dirección general de Carreteras de España. Ingeniería Civil, CEDEXMOPT, 82, pp. 51-56, 1991.

[7] Danish Hydraulic Institute (DHI). MIKE SHE. An integrated hydrological modelling framework-User Guide and Technical Ref. Manual. Edition, 2008.

[8] Bathurst, J.C., Flow resistance estimation in mountain rivers. J. Hydraulic Engineering, ASCE, 111(4), pp. 625-643, 1987.

[9] Fuentes, R. and Aguirre-Pe, J., Resistance to flow in steep rough streams. J. Hydraulic Engineering, 116(11), pp. 1374-1387, 1991.

[10] García Flores, M., Resistencia al flujo en ríos de montaña. Proc. of the XVII IAHR Guayaquil, Ecuador, 1996.

[11] Van Rijn, L.C., Mathematical modelling of morphological processes in the case of suspended sediment transport. Delft Hydraulics Communication No. 382, 1987.

[12] Aguirre-Pe J., Olivero M.L. \& Moncada A.T., Transporte de sedimentos en cauces de alta pendiente. Ingeniería del Agua, 7(4), pp. 353-365, 2000.

[13] Einstein, H.A. and Barbarrosa, N. L., River Channels Roughness. ASCE, 177, pp. 440-457, 1956.

[14] Meyer-Peter, E. \& Müller, R., Formulations of the Bed-load Transport. Proc. of the II IAHR, Stockholm, pp. 39-64, 1948.

[15] Bathurst J.C., Graf, H. \& Cao, H.H. Bed load discharge equations for steep mountains rivers (Chapter 15). Sediment transport in gravel bed rivers, ed. John Wiley and Sons, N.Y, USA, pp. 453-491, 1987.

[16] Yang, S.Q., Sediment Transport Capacity, J. Hydraulic Research, IAHR 43(1), pp. 12-22, 2005. 